\begin{tabular}{|l|l|l||}
\hline Additional \\
Information & $\begin{array}{l}\text { NOTICE: This is the author's version of a work that was accepted for } \\
\text { publication in Toxicology in Vitro. Changes resulting from the } \\
\text { publishing process, such as peer review, editing, corrections, } \\
\text { structural formatting, and other quality control mechanisms may not be } \\
\text { reflected in this document. Changes may have been made to this work } \\
\text { since it was submitted for publication. A definitive version was } \\
\text { subsequently published in Toxicology in Vitro, Vol. 27, Issue 2, (2013). } \\
\text { doi: 10.1016/j.tiv.2012.12.003 }\end{array}$ \\
\hline
\end{tabular}




\title{
Reduced cytotoxicity of silver ions to mammalian cells at high concentration due to the formation of silver chloride
}

\author{
Shaokun Zhang ${ }^{1 \#}$, Chan Du $^{2 \#}$, Zaizhi Wang ${ }^{3 \#}$, Xinguang $\mathrm{Han}^{4 *}$, Kun Zhang ${ }^{5}$, Lihong Liü ${ }^{5 *}$ \\ ${ }^{1}$ Department of Orthopedics, The First Hospital of Jilin University, China \\ ${ }^{2}$ Institute of Bioengineering and Nanotechnology, Singapore \\ ${ }^{3}$ Department of Oral \& Maxillofacial Surgery, The Second Jiaozuo Renmin Hospital, China, \\ ${ }^{4}$ Department of Oral \& Maxillofacial Surgery, the First Affiliated Hospital, Zhengzhou University, China \\ ${ }^{5}$ Department of Chemical Engineering, Curtin University, Australia \\ \# These authors contributed equally to this work \\ *Email:xinguanghan@sina.cn; Lihong.Liu@curtin.edu.au
}




\begin{abstract}
Silver-containing antimicrobial agents are used in various medical products. However, their toxicity to mammalian cells has not been sufficiently evaluated. Numerous studies have unveiled evidence of significant antimicrobial properties associated with $\mathrm{Ag}$ ions. In cell culture media or human body fluids, the free $\mathrm{Ag}^{+}$has rich opportunities to complex with $\mathrm{Cl}^{-}$. Surprisingly, studies on the toxicity of solid form $\mathrm{AgCl}_{(\mathrm{s})}$ to mammalian cells are quite limited. In this study, we evaluated the cytotoxicity of Ag ions and silver chloride colloids on red blood cells and human mesenchymal stem cells (hMSCs). The adverse effects of silver chloride on red blood cells and hMSC were viewed by SEM and LIVE/DEAD viability staining, respectively. Among different tested chemical forms of silver, $\mathrm{AgCl}$ was identified to be the least cytotoxic. Moreover, a decline in the cytotoxicity of $\mathrm{AgCl}$ at significantly high concentrations was observed. We attributed the reduced cytotoxicity to aggregated $\mathrm{AgCl}$ which limited the bioavailability of free $\mathrm{Ag}^{+}$ions.
\end{abstract}

Keywords: silver; silver chloride; cytotoxicity; haemolysis; stem cells; speciation 


\section{Introduction}

Currently, silver-containing antimicrobial agents have gained popularity in the fields of wound-dressing, urinary catheters and cardiovascular implants. Ag nanoparticles are of particular interest because of the enhanced nanomaterial synthesis and characterization techniques. The widespread use of $\mathrm{Ag}$, however, has raised issues concerning $\mathrm{Ag}$ toxicity to aquatic species and humans. $\mathrm{Ag}$ is the second extremely harmful metal after mercury to freshwater fish and invertebrates, with median lethal concentration $\left(\mathrm{LC}_{50}\right)$ values of between 6.5 and $65 \mu \mathrm{g} \mathrm{Ag} / \mathrm{L}$ (Wood, 1996), mainly due to the liberated silver ions. The $\mathrm{Ag}^{+}$toxicity is associated with the perturbation of $\mathrm{Na}^{+}-\mathrm{K}^{+}$transportation and ionoregulation ability of fish thus leading to cardiovascular collapse (Kennedy, 2010). Most recent Ag toxicity studies were focused on nanosilvers (Asharani, 2008). Apart from releasing active $\mathrm{Ag}^{+}$, several studies unravelled that nanosilvers exerted toxic effects on cultured cells by increasing lactate dehydrogenase (LDH) leakage, inhibiting mitochondrial function (Hussain, 2005), producing oxidative stress (Carlson, 2008), damaging DNA (Asharani, 2009) and so on. In cell culture media or human body fluid, the free $\mathrm{Ag}^{+}$has rich opportunities to complex with $\mathrm{Cl}^{-} \mathrm{AgCl}$ formation has been confirmed to protect rainbow trout against silver toxicity (Bielmyer, 2008). Surprisingly, few published studies have reported dissolved silver chloride $\left(\mathrm{AgCl}_{\mathrm{n}}\right)$ toxicology (Rodgers, 1997). The study on potential toxicity of solid form $\mathrm{AgCl}_{(\mathrm{s})}$ to mammalian cells is even more limited. Considering the water solubility of $\mathrm{AgCl}_{(\mathrm{s})}$ is only $0.013 \mathrm{mM}$ (Santoro, 2007) at room temperature, it is essential to understand the toxic involvement of this $\mathrm{Ag}$ speciation.

Since silver-impregnated medical devices are often exposed to the bloodstream, haemolysis evaluation is one of the fundamental tests in determining the safety of such devices. On the other hand, human mesenchymal stem cells (hMSCs) represent a promising cell-based therapy for wound healing and skin regeneration, as they are openly exposed to wound dressing materials. Therefore, the present study was performed to assess the in vitro acute toxicity of silver nitrate in comparison with silver chloride colloids to red blood cells and bone marrow derived hMSCs. Most of the earlier studies evaluated the Ag cytotoxicity at relatively low doses. For example, Sopjani et al. (2009) has reported that at concentrations of $100-500 \mathrm{nM} \mathrm{Ag}^{+}$triggered eryptosis by interfering with the energy balance. Employing comet assay and chromosomal aberration tests, Hackenberg (2011) demonstrated hMSCs DNA damage by 1 to $100 \mu \mathrm{M}$ Ag nanoparticles. However, Ag susceptibility studies have produced different minimal inhibition concentrations (MIC) data due to complex solubility issues that affect the bioavailability of Ag ions. Kim et al. (2007) determined the MIC of Ag nanoparticles to be $3.5 \mathrm{ng} / \mathrm{mL}$ for Staphylococcus aureus, while other Ag microbiocidal studies have revealed the MICs against Escherichia coli and Staphylococcus aureus could range from 74 to $740 \mu \mathrm{M}$ (Chopra, 2007). Hence, acute cytotoxicity assessment of silver species at high concentrations becomes necessary to guarantee a safe therapeutic-window. We attempted to investigate toxic effects of $\mathrm{Ag}$ ions from 0.0075 to $5.0 \mathrm{mM}$. We assumed that $\mathrm{Ag}$ ions would react with chloride ions and therefore reduce the cytotoxicity. In particular, the formation of silver chloride and its functional impairment to the above mentioned mammal cells were investigated. The particles were characterized by dynamic light scattering. The adverse effects of silver chloride on red blood cells and hMSCs were viewed by SEM and LIVE/DEAD viability staining, respectively. 


\section{Material and Methods}

\subsection{Chemicals}

Silver nitrate was purchased from Sigma-Aldrich. De-ionized (DI) water was distilled by a Milli-Q water purification system. 1 x Phosphate-buffered saline (PBS) was ordered from Invitrogen.

\section{2. $\mathrm{AgCl}$ colloids preparation}

$34 \mathrm{mg}$ silver nitrate was dissolved in $10 \mathrm{~mL}$ DI water to get a $20 \mathrm{mM}$ stock solution. Silver chloride was formed immediately after mixing $\mathrm{AgNO}_{3}$ with PBS. The particle growth and precipitation was monitored by DLS.

\subsection{Haemolysis}

Rabbit and rat red blood cell (RBC) samples were obtained from apparently healthy animals that were housed in the Experimental Animal Unit of Jilin University. The cells were diluted in PBS (4 vol \%) for haemolysis study. $\mathrm{AgNO}_{3}$ stock solution $(20 \mathrm{mM})$ was used as a source of silver ions. The stock solution was diluted by adding DI water to obtain free silver ion concentrations which ranged from 0.08 to $5 \mathrm{mM}$. From DLS characterization results, we know the $\mathrm{AgCl}$ colloidal solution was stable only for about $1 \mathrm{~h}$. To distinguish the cytotoxicity of free $\mathrm{Ag}^{+}$ions and $\mathrm{AgCl}$ colloids, we always freshly prepared $\mathrm{AgCl}$ colloids by vigorously mixing $1 \mathrm{~mL}$ of silver nitrate solution and $1 \mathrm{~mL}$ of PBS solution. After $30 \mathrm{~min}$, the cell suspension was mixed with $\mathrm{Ag}^{+}$and colloidal $\mathrm{AgCl}$ and incubated for $1 \mathrm{~h}$ at $37^{\circ} \mathrm{C}$ in the minishaker. A control solution that contained only PBS was used as a reference for $0 \%$ hemolysis. Triton X-100 at a concentration of $0.5 \%$ served as a positive control. The released haemoglobin concentration was measured at $576 \mathrm{~nm}$.

$$
\text { Hemolysis }(\%)=\frac{O D_{576 \text { oligomer }}-O D_{57 \text { bblank }}}{O D_{576 \text { riton } X 100}-O D_{57 \text { bblank }}} \times 100
$$

3.

\subsection{Human mesenchymal stem cell culture, staining and cytotoxicity study}

Human bone marrow-derived MSCs (Cambrex, Walkersville, MD) were cultured in Mesenchymal Stem Cell Growth Medium with $1 \%$ penicillin/streptomycin. The cells were subcultured three times after reaching $90 \%$ confluence at $37^{\circ} \mathrm{C} / 5 \% \mathrm{CO}_{2}$. Passage $5 \mathrm{hMSCs}$ were seeded at the density of $1 \times 10^{4} /$ well (in 96-well plate) in either fresh media containing (1) 0.0075 to $10 \mathrm{mM}$ silver nitrate, (2) 0.0075 to $10 \mathrm{mM} \mathrm{AgCl}$ colloids aged for $30 \mathrm{~min}$.

To visualize the cell attachment and morphology after incubation with silver compounds, in the form of either silver nitrate or silver chloride colloids, the cells were stained with the LIVE/DEAD ${ }^{\circledR}$ cell viability/cytotoxicity kit (Molecular Probes) for $30 \mathrm{~min}$, and examined using an Olympus BX61 microscope.

The cell viability was examined using 3-(4, 5-dimethylthiazol-2-yl)-5-(3-carboxymethoxyphenyl)-2-(4-sulfophenyl)-2H-tetrazolium (MTS) assay. Cells were allowed to attach in 24-well plates in $1 \mathrm{~mL}$ of medium with different concentrations of silver nitrate or silver chloride colloids. After overnight incubation at $37{ }^{\circ} \mathrm{C}$ in $5 \% \mathrm{CO}_{2}$, the light absorbance was measured at $490 \mathrm{~nm}$ with a microplate reader. The cell viability was expressed as the ratio of the number of viable cells with Ag treatment to that without treatment. Experiments were repeated in triplicates, and consistent results were obtained.

\subsection{Red blood cell preparation for SEM}

The shape changes of red blood cells incubated with $\mathrm{AgCl}$ colloids were observed using a field emission SEM (JEOL JSM-6701F). The cells were harvested by centrifugation at 1500 
rpm for 5 min. They were washed with PBS three times and then fixed in PBS containing 2.5\% glutaraldehyde for $1 \mathrm{~h}$. The cells were further washed with DI water, followed by dehydration using a series of ethanol washes. Several drops of the suspension were placed on a carbon tape and left to dry under room temperature. The samples were coated with platinum prior to SEM analyses.

\subsection{Statistical analysis}

All the experiments were replicated three times. The results of dose-response haemolysis are presented as means \pm standard deviations (S.D.) of three separate experiments with the aid of Windows Excel computer software.

\section{Results}

3.1. Silver chloride particle characterization

We prepared colloidal $\mathrm{AgCl}$ at total $\mathrm{Ag}$ concentrations ranging from 0.02 to $2.0 \mathrm{mM}$.

$\mathrm{AgCl}$ colloids seemed easily agglomerated or aggregated in PBS at high concentrations. When 0.31 to $2.0 \mathrm{mM} \mathrm{AgNO}_{3}$ was reacted with PBS, the colour of solution changed from transparent to light blue, grey and colourless within $4 \mathrm{~h}$. Visible precipitates settled to the bottom were further revealed by light microscope (Fig. 1). The individual primary grains formed are roughly circular, close inspection reveals particles of $\sim 5 \mu \mathrm{m}$ diameter. The aggregates gradually assembled into a network of branching, treelike shapes with dimensions exceeding hundreds of micrometer range. Similarly, Choi et al. (2011) revealed that $\mathrm{AgCl}$ tends to form larger particles. The settled precipitates definitely exceeded the nanometric range in dimensions. No obvious precipitation was observed within $1 \mathrm{~h}$ when $\left[\mathrm{AgNO}_{3}\right] \leq 0.16$ $\mathrm{mM}$.

\subsection{Haemolytic properties of $\mathrm{Ag}^{+}$and $\mathrm{AgCl}$ colloid}

In Fig. 2, the haemolysis percentage of rat blood cells caused by $\mathrm{Ag}^{+}$in DI and pre-formed $\mathrm{AgCl}$ was compared after $1 \mathrm{~h}$ incubation at $37^{\circ} \mathrm{C}$. As expected, haemolysis induced by $\mathrm{Ag}^{+}$ indicated a dose-dependent increase from $0.02 \mathrm{mM}$ to $0.16 \mathrm{mM}$, the haemolytic percentages of rat red blood cells incubated with $0.02,0.04,0.08$ and $0.16 \mathrm{mM} \mathrm{AgNO}_{3}$ were 50\%, 80\%, $90 \%$ and $100 \%$, respectively; however, haemolysis dropped significantly at $0.31 \mathrm{mM}(80 \%)$ and even lower at $0.625 \mathrm{mM}(50 \%)$. At concentrations above $0.625 \mathrm{mM}$, the measured haemolytic percentages were maintained at $40 \%$. Although colloidal $\mathrm{AgCl}$ was not haemolytic at $0.04 \mathrm{mM}$, similar to the case of $\mathrm{Ag}^{+}$, it showed the maximum haemolysis at $0.16 \mathrm{mM}$ and a declined haemolytic property from $0.31 \mathrm{mM}$. Unlike rat RBCs, rabbit RBSs were extremely fragile to silver toxicity. $\mathrm{Ag}^{+}$in DI water caused $100 \%$ rabbit $\mathrm{RBCs}$ haemolysis from 0.02 to $2.5 \mathrm{mM}$. Even the formation of $\mathrm{AgCl}$ colloids (from 0.08 to $2.5 \mathrm{mM}$ ) did not protect the rabbit RBCs from being haemolyzed.

\subsection{Red blood cell morphology changes}

In agreement with quantity results of haemoglobin release, morphological changes of rat red blood cells observed by light microscope displayed that, while control cells kept a typical biconcave shape, exposure of rat $\mathrm{RBCs}$ to $\mathrm{Ag}^{+}$in DI caused serious haemolysis and showing many ghost cells. The number of ghost cells increased with increasing concentration of $\mathrm{Ag}^{+}$ from 0.16 to $0.62 \mathrm{mM}$ (Fig. 3). We hypothesized that haemoglobin wrapped inside these cell fragments contributed to the lower haemoglobin readings. Exposure of $\mathrm{RBCs}$ to $\mathrm{AgCl}$ colloids did not exhibit apparent morphological changes at $0.02 \mathrm{mM}$. Haemolysis started at $0.04 \mathrm{mM}$ and less RBCs were left at concentrations from 0.08 to $0.31 \mathrm{mM}$. Surprisingly, the light microscope images showed more swollen cells and less ghost cells as the $\mathrm{AgCl}$ colloids concentration increased to $0.62 \mathrm{mM}$. These echinocyte II/III cells were further characterized 
by SEM. The SEM micrographs (Fig. 4) showed loss of biconcave structure and ruffled membrane on the surface of RBCs.

\section{4. hMSCs morphology alterations and cytotoxicity evaluation}

After overnight incubation, a dose-dependent (from 0.0075 to $0.125 \mathrm{mM}$ ) cell death induced by Ag was confirmed by MTS test. At a concentration of $0.125 \mathrm{mM}$, silver nitrate killed $86 \%$ cells as evidenced by necrosis cells lifting of 96-well plate surface. Incubation with the high concentrations of Ag, in contrary, left cells still attached on tissue culture plate surface, which indicated the absence of cellular necrosis. Treated cells appeared to have shrunk with a few cellular extensions as compared to control cells. The restricted cell spreading patterns could be due to damage to cytoskeletal functions by $\mathrm{AgCl}$ colloids. Similar results were observed by Asharani et al. in human glioblastoma cells (U251) treated with $200 \mu \mathrm{g} / \mathrm{mL} \mathrm{Ag-starch}$ nanoparticles. The cells were observed even at $10 \mathrm{mM}$, with white patches on the cell body.

\section{Discussion}

With the rapidly expanding use of Ag in medical applications, especially for the management of burn patients, human exposure is frequent and so evaluation of their potential cytotoxicity becomes essential. Former studies have identified the toxic outcome of silver in several in vitro cell systems and in vivo animal models. The current study compares cytotoxic potentials of $\mathrm{Ag}^{+}$and $\mathrm{AgCl}$ to red blood cells and hMSCs. To assess the impact of $\mathrm{AgCl}$ formation on ionic silver cytotoxicity, we separately tested haemolysis of free $\mathrm{Ag}$ ions in DI and preformed $\mathrm{AgCl}$ colloidal in PBS. Free $\mathrm{Ag}$ ions at concentration of $0.02 \mathrm{mM}$ caused significant rat blood haemolysis (50\%). Contrary to the expectation, silver ions of higher concentration (above $0.31 \mathrm{mM}$ ) were less haemolytic than $0.16 \mathrm{mM}$. Although pre-formed $\mathrm{AgCl}$ colloids caused dramatically less haemolysis than $\mathrm{Ag}^{+}$at doses 0.02 to $0.16 \mathrm{mM}$, similar to the case of free ions, $\mathrm{AgCl}$ colloids induced the maximum haemolysis at $0.16 \mathrm{mM}$. At higher doses (0.31- $5.0 \mathrm{mM}$ ), the haemolytic difference of $\mathrm{Ag}^{+}$and $\mathrm{AgCl}$ colloids was not obvious by measuring released haemoglobin amount, but the morphology changes were totally different which will be discussed later. Previously, most studies indicated a dose-dependent increase in lesions related to various levels of silver exposure. To our knowledge this is the first study to disclose the existence of such a turning-point. Although the exact mechanism underlying this critical point is yet to be elucidated, one possible explanation for this would be the variation of the reactive oxygen species (ROS) does not follow a dose-dependent manner. Panda et al. (2011) prepared $\mathrm{Ag}^{+}, \mathrm{Ag}$ nanoparticles and colloidal $\mathrm{AgCl}$ for sake of genotoxicity and cytotoxicity evaluation on onion bulb cells. In their study, one kind of $\mathrm{ROS}, \mathrm{O}_{2}{ }^{-}$, generated by $\mathrm{Ag}^{+}$indicated a significant dose-dependent increase in the range $0-0.37 \mathrm{mM}$, however, $\mathrm{O}_{2}{ }^{-}$ content dropped remarkably at the next highest concentration $(0.74 \mathrm{mM})$. Evidence of ROS leading to lipid peroxidation of the RBC membrane and haemolysis has been reported before (Clark, 1983, Asharani, 2010), taken together, our data could suggest a correlation between $\mathrm{AgCl}$ colloids and free radicals generation.

Recent reports have established the binding of $\mathrm{Ag}^{+}$ions with dissolved organic matter, thiosulfate and chloride might lead to a mitigated toxicity of silver species (Hogstrand, 1996; Russell, 1998). We hypothesize the reduced cytotoxicity of $\mathrm{Ag}^{+}$was due to the formation of $\mathrm{AgCl}$ colloids.

To assess the impact of $\mathrm{Cl}^{-}$presence on haemolysis, the formation and growth of $\mathrm{AgCl}$ in PBS (total $\left[\mathrm{Cl}^{-}\right]=139.6 \mathrm{mM}$ ) was studied. $\left[\mathrm{Cl}^{-}\right]$was much higher than the added $\left[\mathrm{Ag}^{+}\right]$which would ensure complete complexation of $\mathrm{Ag}^{+}$ions. At low $\mathrm{Ag}^{+}$concentration $(0.08$ and 0.16 $\mathrm{mM}$ ), no $\mathrm{AgCl}$ precipitation was observed after mixing with PBS (Fig. 1) within $1 \mathrm{~h}$. As the 
$\mathrm{Ag}^{+}$became more concentrated, for example, at $\left[\mathrm{AgNO}_{3}\right]=0.31 \mathrm{mM}, \mathrm{AgCl}$ colloids were observed to become bigger in size as a function of time. The mean diameter of $\mathrm{AgCl}$ colloids (at 5, 10, 15, 20, 25 and 30 m) measured by DLS was 79, 105, 137, 179, 222 and 387 $\mathrm{nm}$, respectively. Whereas the reaction time was longer, the presence of sedimenting particles (5080 $\mu \mathrm{m}$ in diameter) were detected by the DLS instrument. The poor data quality was not good enough for DLS characterization after $30 \mathrm{~m}$. These findings suggest that at high concentrations $\mathrm{AgCl}$ colloids are not stable at all. Potential change of $\mathrm{AgCl}$ colloidal particle size over time, however, is often ignored by some earlier studies. For example, Choi et al. (2008) prepared $0.7 \mathrm{mM} \mathrm{AgCl}$ colloidal particles by mixing $1 \mathrm{~mL}$ of $14 \mathrm{mM}$ silver nitrate and $1 \mathrm{~mL}$ of $28 \mathrm{mM}$ sodium chloride with $18 \mathrm{~mL}$ of distilled water. The particle sizes were reported from 0.1 to $2 \mu \mathrm{m}$ with an average diameter of $0.25 \mu \mathrm{m}$. The authors could interpret experimental results more precisely by incorporating the aging time of their $\mathrm{AgCl}$ colloids before adding them to the tested microorganisms. The particle size measured over the duration of toxicological bioassays may enhance our insights on the nature of the $\mathrm{Ag}$ exposure. The stock solution of $\mathrm{AgCl}$ prepared by Panda et al. (2011) was also very high at $1.48 \mathrm{mM}$. Again, the descriptions of $\mathrm{AgCl}$ size and aggregation diverged from detailed to very limited. Based on our observation, even at a concentration of $1.25 \mathrm{mM}, \mathrm{AgCl}$ colloids rapidly precipitated within $15 \mathrm{~min}$. This information is highly important, since the dispersion status of tiny particles might affect the subsequent toxicity.

We speculate that three major reasons are associated with the reduced cytotoxicity of $\mathrm{Ag}^{+}$ observed in our study. First of all, a decreased concentration of $\mathrm{Ag}^{+}$is expected due to the formation of $\mathrm{AgCl}$ that consumed $\mathrm{Ag}^{+}$. Secondly, like the ionic $\mathrm{Ag}^{+}$may sorb to silver nanoparticles (Liu, 2010), high $\mathrm{AgCl}$ colloidal concentrations will provide more surfaces for $\mathrm{Ag}^{+}$binding. Thirdly, at higher initial $\left[\mathrm{AgNO}_{3}\right]$ concentration, primary colloids formed aggregates faster which limits the dissociation of free $\mathrm{Ag}^{+}$.

In parallel, we performed $\mathrm{Ag}$ ions and $\mathrm{AgCl}$ colloids haemolysis studies on rabbit red blood cells. At the same concentration, Ag caused different haemolysis between rat and rabbit RBCs. Rabbit RBCs are more sensitive to Ag than rat RBCs. For example, 0.63 and $1.25 \mathrm{mM}$ $\mathrm{AgCl}$ caused $80 \%$ and $30 \%$ rat blood cell lysis, but still caused $100 \%$ haemolysis of rabbit blood cells. The reduced haemolysis due to $\mathrm{AgCl}$ formation was not observed until $\left[\mathrm{AgNO}_{3}\right]$ $=5 \mathrm{mM}$. The difference may be related to the nature of the red blood cell membrane. It is suggested that the phospholipid composition of the red cell membrane is characteristic for each animal species (Kasarov, 1970), therefore leptospirae also caused different red blood cell degradation among tested animals. Contrasting effects of chloride protection on the toxicity of silver are documented in the earlier studies for different test species. For example, Lee et al. (2005) tested the inhibition growth of two green algae, $C$. reinhardtii and $P$. subcapitata exposure to dissolved silver. The two algae differ in their response to the attenuation of silver chloride complexes. In a comparison of $\mathrm{Ag}^{+}$toxicity to rainbow trout and European eel, Grosell et al. (2000) found marked fish species-specific differences. The different silver tolerance with the presence of ambient $\mathrm{Cl}^{-}$was related to the differences in whole body $\mathrm{Na}^{+}$turnover rates and differences in chloride homeostatic mechanisms.

SEM analysis of rat red blood cells following $0.6 \mathrm{mM} \mathrm{AgCl}$ colloid exposure unveiled the surface characteristics of rat RBCs at an early stage of haemolysis. In addition to the swollen cell body as shown in light microscope images, $\mathrm{AgCl}$ exposure resulted in multiple groves on the surface of RBCs. At high magnification, numerous pores on the cell membrane were disclosed. Therefore, the morphologic alterations in rat RBCs can be induced by changes in the cell membrane. Our SEM results are consistent with those AFM studies recently reported 
by Asharani et al. (2010). In their study, the authors attributed the swollen echinocytes to the damaged membrane that further challenged the osmotic barrier, thus resulting in increased water uptake by the cells.

Following overnight incubation, it was found that $\mathrm{Ag}^{+}$was extremely toxic to hMSCs, they induced significant necrosis at $0.125 \mathrm{mM}$. However, as shown in Fig. 5, no dose-response was observed in cells treated by $\mathrm{AgCl}$ colloids at higher concentrations $(0.25$ to $10 \mathrm{mM})$; indeed, $0.5 \mathrm{mM} \mathrm{AgCl}$ treated cells displayed less cellular shrinkage than $0.12 \mathrm{mM}$. The absence of massive cell death indicated $\mathrm{AgCl}$ treatment mainly resulted hMSCs apoptosis.

Although our data provided some factors that should be considered in assessing $\mathrm{AgCl}$ colloids cytotoxicity, further molecular level studies are required in order to understand the mode of cytotoxic mechanisms.

\section{Conclusions}

In summary, ionic Ag exhibited dramatically higher cytotoxicity than that of pre-formed $\mathrm{AgCl}$ colloid. The current study reinforces the importance of $\mathrm{Cl}^{-}$interaction in acute $\mathrm{Ag}$ ions toxicity evaluation. Our results confirm the protection role of $\mathrm{Cl}^{-}$, on both red blood cells and hMSCs, especially at high doses far beyond previously investigated concentrations. Moreover, $\mathrm{AgCl}$ colloids at high concentrations were found to aggregate and to settle within $30 \mathrm{~m}$. The absence of standard aging time will undoubtedly complicate interpretation of $\mathrm{Ag}$ acute toxicity data. In order to reduce the discrepancies among different laboratory cytotoxic studies, it would be beneficial to specify detailed experimental conditions.

\section{Conflict of interest statement}

The authors declare that they have no conflict of interest.

\section{Acknowledgement}

This study was supported by Australian Research Council under grant number DP110104599. DLS analysis was carried out at Nanochemistry Research Institute of Curtin University. 


\section{References}

Asharani, P.V., Wu, Y. L., Gong, Z., Valiyaveettil, S., 2008. Toxicity of silver nanoparticles in zebrafish models. Nanotechnology 19, 255102-255110.

AshaRani, P. V., Low, G.K.M., Hande, M. P., Valiyaveettil, S., 2009. Cytotoxicity and genotoxicity of silver nanoparticles in human cells. ACS Nano 3, 279-290.

Asharani, P. V., Sethu, S., Vadukumpully, S., Zhong, S., Lim, C.T., Hande, M. P., Valiyaveettil, S., 2010. Investigations on the structural damage in human erythrocytes exposed to silver, gold, and platinum nanoparticles. Adv. Funct. Mater. 20, 1233-1242.

Bielmyer, G.K. Brix, K.V., Grosell, M., 2008. Is $\mathrm{Cl}^{-}$protection against silver toxicity due to chemical speciation? Aquat. Toxicol. 87, 81-87.

Carlson, C., Hussain, S.M., Schrand, A.M., Braydich-Stolle, L.K., Hess, K.L., Jones, R.L., Schlager, J.J., 2008. Unique cellular interaction of silver nanoparticles: size dependent generation of reactive oxygen species. J. Phys. Chem. B 112, 13608-13619.

Choi, J., Reipa,V., Hitchins,V.M., Goering, P.L. Malinauskas, R.A., 2011. Physicochemical characterization and in vitro haemolysis evaluation of silver nanoparticles. Toxicol. Sciences 123, 133-143.

Choi O., Deng, K. K., Kim, N., Jr., L. R., Surampallie, R. Y., Hua, Z., 2008. The inhibitory effects of silver nanoparticles, silver ions, and silver chloride colloids on microbial growth. Water Research. 42, 3066 - 3074.

Chopra, I., 2007. The increasing use of silver-based products as antimicrobial agents: a useful development or a cause for concern? J. Antimicrob. Chemother. 59, 587-590.

Clark, I.A., Hunt, N.H., 1983. Evidence for reactive oxygen intermediates causing hemolysis and parasite death in malaria. Infect. Immun. 39, 1-6.

Erickson, R.J., Brooke, L.T., Kahl, M.D., Venter, F.V., Harting, S.L., Markee, T.P., Spehar, R.L., 1998. Effects of laboratory test conditions on the toxicity of silver to aquatic organisms. Environ. Toxicol. Chem. 17, 572-578

Grosell, M., Hogstrand, C., Wood, C.M., Hansen, H.J.M. 2000. A nose-to-nose comparison of the physiological effects of exposure to ionic silver versus silver chloride in the European eel (Anguilla anguilla) and the rainbow trout (Oncorhynchus mykiss). Aquat. Toxicol. 48, 327-342.

Hackenberg, S., Scherzed, A., Kessler, M., Hummel, S., Technau, A., Froelich, K., Ginzkey, C., Koehler, C., Hagen, R., Kleinsasser, N., 2011. Silver nanoparticles: evaluation of DNA damage, toxicity and functional impairment in human mesenchymal stem cells. Toxicol. Lett. 201, 27-33.

Hogstrand, C., Galvez, F., Wood, C.M., 1996. Toxicity, silver accumulation and metallothionein induction in freshwater rainbow trout during exposure to different silver salts. Environ. Toxicol. Chem. 15, 1102-1108.

Hussain, S. M., Hess, K. L., Gearhart, J. M., Geiss, K. T., Schlager, J. J., 2005. In vitro toxicity of nanoparticles in BRL 3A rat liver cells. Toxicol. In Vitro 19, 975-983. 
Kasarov, L.B., 1970. Degradation of the erythrocyte phospholipids and haemolysis of the erythrocytes of different animal species by leptospirae. J. Med. Microbiol. 29-37.

Kennedy, A. J., Hull, M.S., Bednar, A. J., Goss, J.D., Gunter, J.C., Bouldin, J.L., Vikesland, P.J., Steevens, J.A., 2010. Fractionating nanosilver: importance for determining toxicity to aquatic test organisms. Environ. Sci. Technol. 44, 9571-9577.

Kim, J., Kuk, E., Yu, K., Kim, J., Park, S., Lee, H., Kim, S., Park, Y.H., Hwang, C., Kim, Y., Lee, Y., Jeong, D., Cho, M., 2007. Antimicrobial effects of silver nanoparticles. Nanomedicine 3, 95-101.

Kim, S., Choi, J. E. Choi, J., Chung, K., Park, K., Yi, J., Ryu, D., 2009. Oxidative stressdependent toxicity of silver nanoparticles in human hepatoma cells, Toxicol. In Vitro 23, 1076-1084.

Lee, D., Fortin, C., Campbell, P.G.C., 2005. Contrasting effects of chloride on the toxicity of silver to two green algae, Pseudokirchneriella subcapitata and Chlamydomonas reinhardtii. Aquat. Toxicol. 75, 127-135.

Liu, J., Hurt, R.H., 2010. Ion release kinetics and particle persistence in aqueous nanosilver colloids. Environ. Sci. Technol. 44, 2169-2175.

Panda, K.K, Achary, V.M.M., Krishnaveni, R., Padhi, B.K., Sarangi, S.N., Sahu, S.N., Panda, B.B., 2011. In vitro biosynthesis and genotoxicity bioassay of silver nanoparticles using plants. Toxicol. In Vitro. 25, 1097-1105.

Rodgers, J. H., Deaver, J., E., Suedel, B. C., Rogers, P. L., 1997. Comparative aqueous toxicity of silver compounds: laboratory studies with freshwater species. Bull. Environ. Contam. Toxicol. 58, 851-858.

Santoro, C.M., Duchsherer, N.L., Grainger, D.W., 2007. Antimicrobial efficacy and ocular cell toxicity from silver nanoparticles. Nanotechnology. 3, 55-65.

Sopjani, M., Föller, M., Haendeler, J., Götz F., Lang, F., 2009. Silver ion-induced suicidal erythrocyte death. J. Appl. Toxicol. 29, 531-536.

Wood, C.M., Hogstrand, C., Galvez, F., Munger, R.S., 1996. The physiology of waterborne silver toxicity in freshwater rainbow trout (Oncorhynchus mykiss) 1 . The effects of ionic $\mathrm{Ag}^{+}$. Aquat. Toxicol. 35, 93-109. 


\section{Figures}

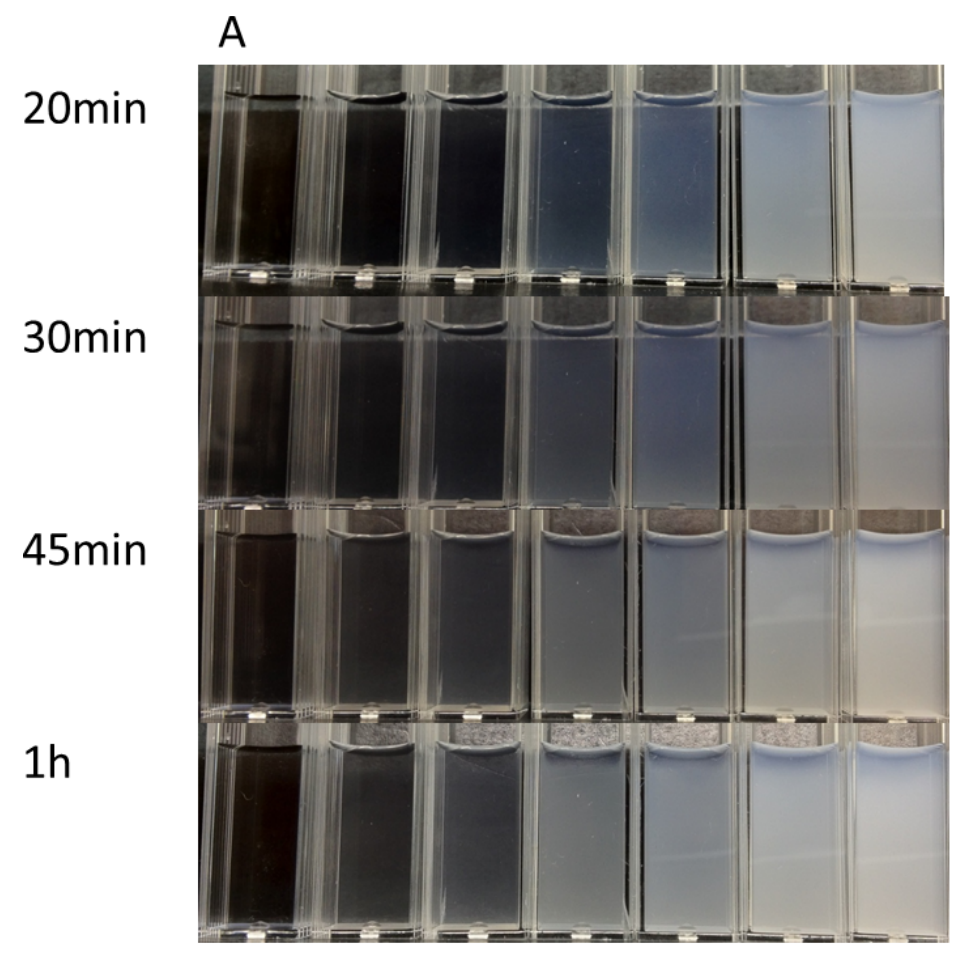

B

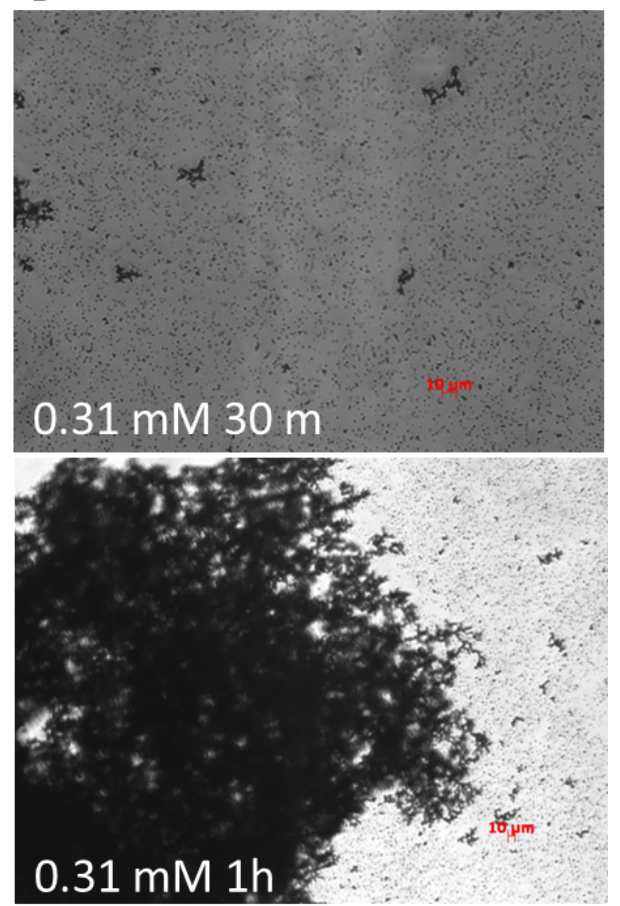

PBS $0.08 \quad 0.16 \quad 0.310 .62 \quad 1.25 \quad 2.0$

Fig. 1. Unstable $\mathrm{AgCl}$ colloids formed after mixing $\mathrm{AgNO}_{3}$ with phosphate-buffered saline.

(A) Gradually increased level of $\mathrm{AgCl}$ aggregation was obvious with higher concentrations of $\mathrm{AgNO}_{3}(0.08$ to $2.0 \mathrm{mM}$ ) and longer aging time (20 min to $1 \mathrm{~h}$ ). (B) Light microscopic images of typical $\mathrm{AgCl}$ colloids at $30 \mathrm{~min}$ and $1 \mathrm{~h}$. Initial $\left[\mathrm{AgNO}_{3}\right]=0.31 \mathrm{mM}$.
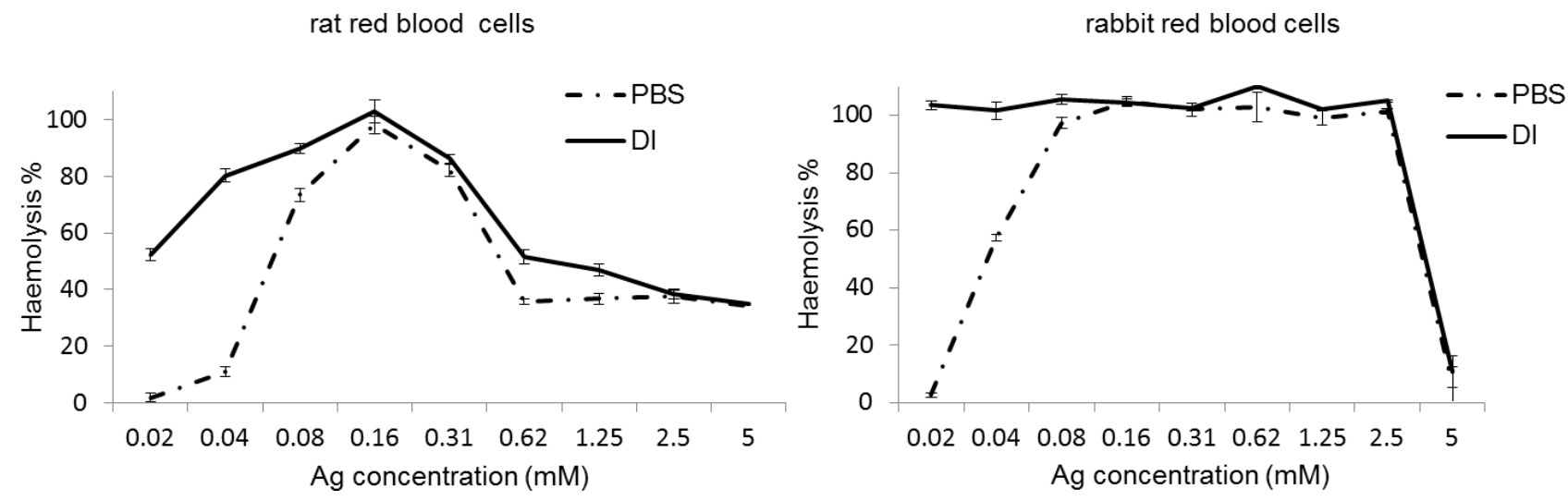

Fig. 2. Heamolysis percentages of rat and rabbit red blood cells caused by $\mathrm{Ag}^{+}$ions in deionized water and pre-formed $\mathrm{AgCl}$ colloids. Data are presented as the mean \pm S.D. $(n=3)$. 


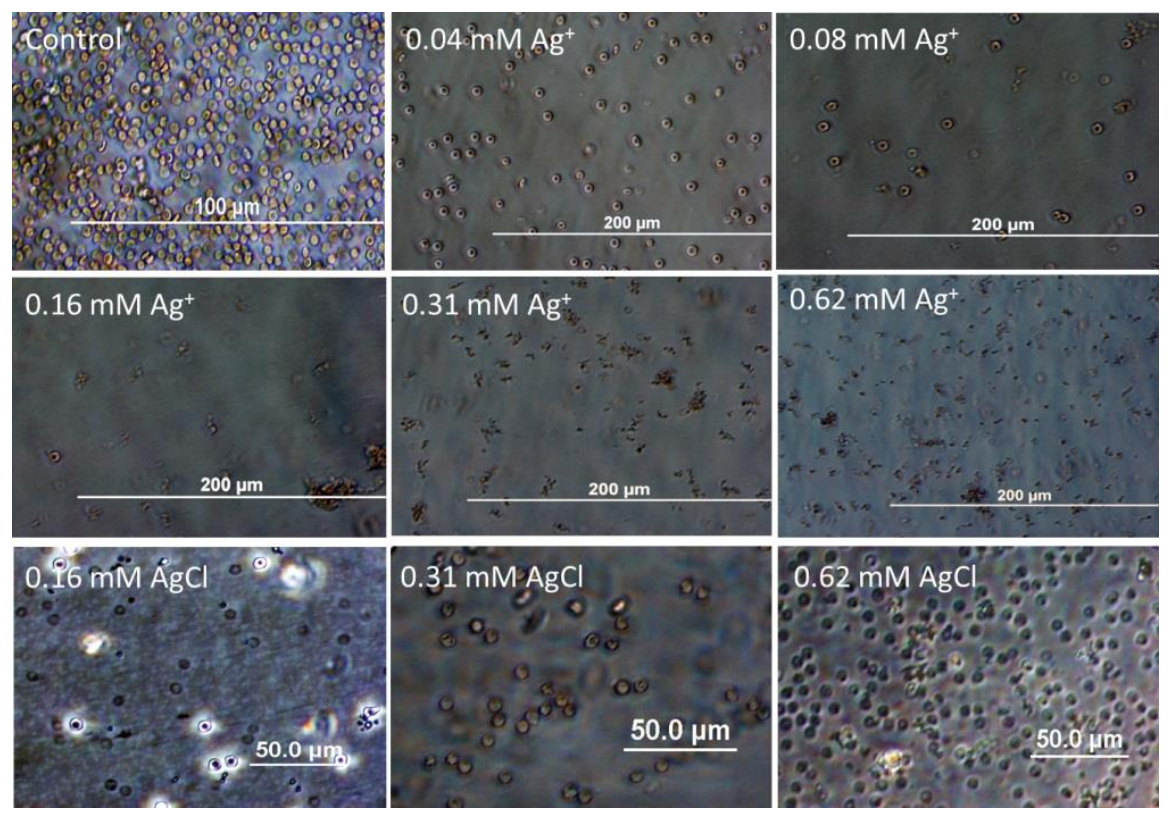

Fig. 3. Morphological observation of rat red blood cells exposure to $\mathrm{Ag}^{+}$ions and $\mathrm{AgCl}$ colloids.
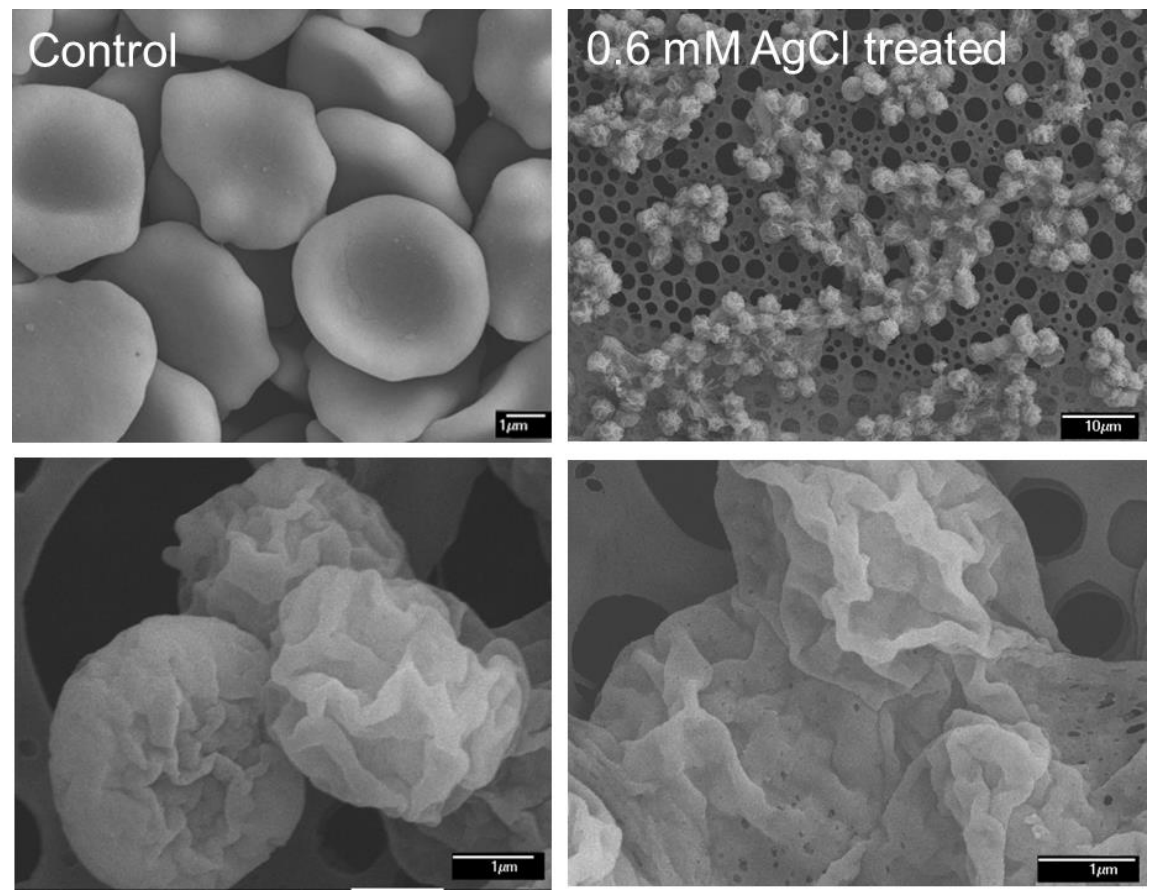

Fig. 4. Scanning electron microscopic images of rat red blood cells before and after treated with $0.62 \mathrm{mM} \mathrm{AgCl}$ colloids. 


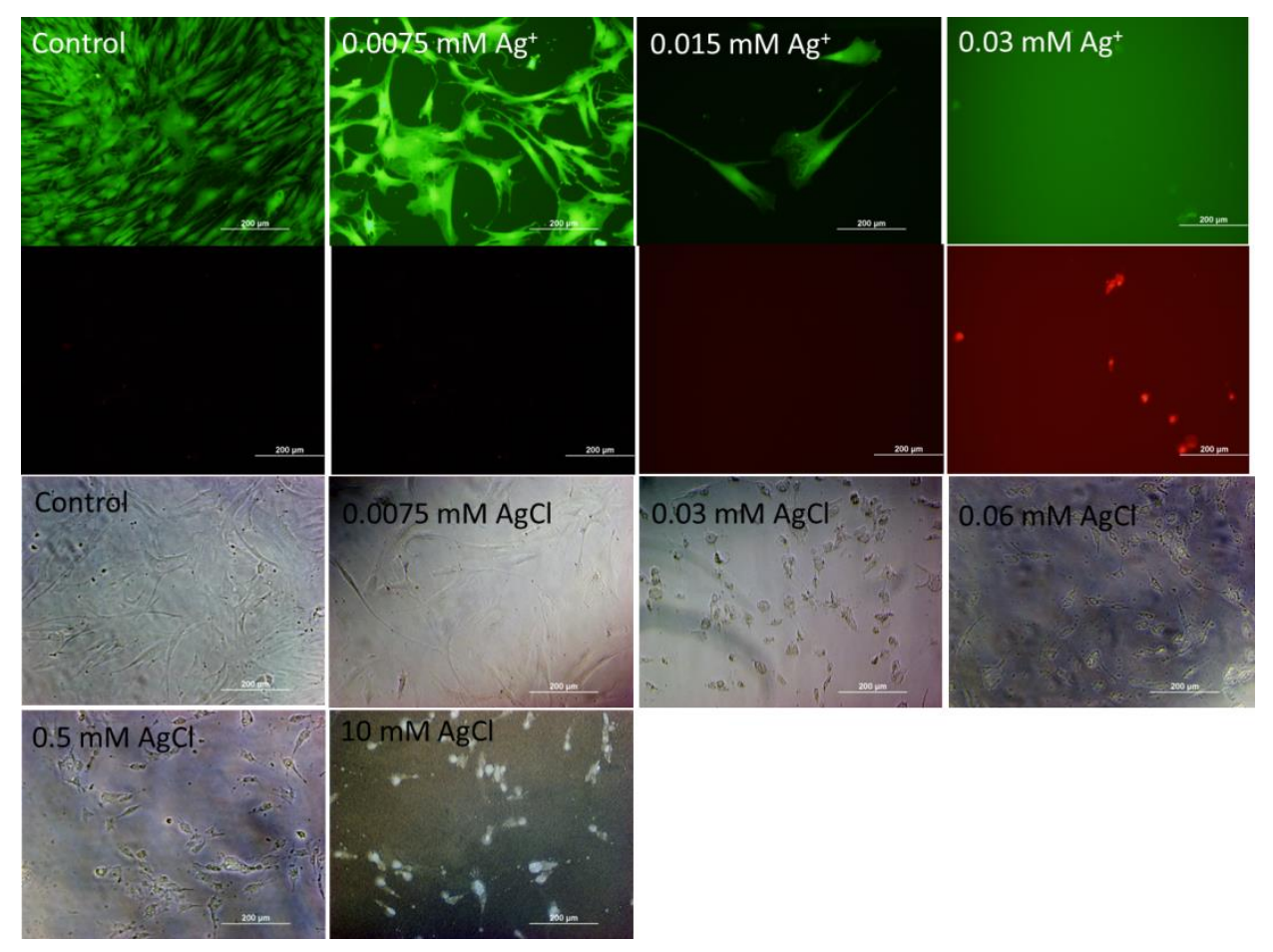

Fig. 5. $\mathrm{Ag}^{+}$in de-ionized water caused necrosis of human mesenchymal stem cells (hMSCs) while $\mathrm{AgCl}$ colloids led to apoptosis of the cells. 